Journal of Teacher Education for Sustainability, vol. 21, no. 2, pp. 5-16, 2019

\title{
Measuring Teachers-As-Learners' Digital Skills and Readiness to Study Online for Successful e-Learning Experience
}

\author{
Evija Mirḳe \\ Riga Technical University, Riga, Latvia \\ Sarma Cakula \\ Vidzeme University of Applied Sciences, Valmiera, Latvia \\ Lilian Tzivian \\ University of Latvia, Riga, Latvia
}

\begin{abstract}
Previous studies have analysed the need to measure learners' readiness for online learning. In the framework of education reform in Latvia, by the end of 2021 the National Centre for Education will implement online courses for all school teachers. However, there is a lack of studies investigating teachers-as-learners' readiness to study online in Latvia. The aim of the study was to assess Latvian teachers' readiness to study online with focus on the differences of respondents' socio-demographic or professional characteristics. 1092 teachers from 100 schools filled in the self-evaluation survey form online. Statistically significant differences were found in all subscales of the survey. Differences in digital skills and in readiness to study online were found at all education levels by respondents' gender, age group or place of living. Younger respondents, males or city inhabitants showed higher rates. E-learning course should be customized, taking into account learners' socio-demographic parameters and online learning readiness rate.
\end{abstract}

Key words: digital skills, e-learning, lifelong learning, online learning, self-paced learning, teachers-as-learners, teacher education

\section{Introduction}

Lifelong learning involves certain challenges depending on biographical influences of teachers-as-learners that have already developed their learning styles and learning competences. Learning experiences of teachers are often influenced by their childhood experiences - learning at school, university, digital learning, informal learning and some others. For sustainability of lifelong learning, one should create a combination of innovation and tradition in an integrative way (Salìte, 2009; Salìte et al., 2013, 2018; Franzenburg, 2017; Kapenieks \& Salīte, 2013). 
In "Education Policy Outlook 2015" about education reforms in member countries of the Organisation for Economic Co-operation and Development (OECD), development of the digital society is mentioned as one of three key reasons to invest in the education reform. In general, development of information and telecommunication technologies (ICT) has led to a different approach to communication, growth of social networks, increased role of technologies in all spheres of life, including education (OECD, 2015).

Latvia is one of the OECD countries currently reforming the general education system. In school year 2017/18, there were 33450 full-time-equivalent teachers in general education in Latvia, including pre-schools (WEB, a). The OECD reported $89 \%$ female teachers in Latvia, compared to the OECD average of $68 \%$ (Schwabe, 2019). The academic performance of Latvian pupils over recent years has been worrisome: the key findings of the Programme for International Student Assessment (PISA) 2015 show that Latvian pupils' performance in mathematics and reading is below the OECD average; only in science Latvian pupils' performance is around the OECD average. All the results have been stable since 2006 (WEB, b). If the tendency continues, it may limit pupils' future possibilities to advance their careers and professional development in the global market.

In these circumstances, changes are required. Therefore, the Ministry of Education and Science has proposed a reform in general education in Latvia. Starting from autumn 2019, the reform is implemented by the National Centre for Education (NCE) in form of European Social Fund "Competency-Based Curriculum" project (WEB, c). The new curriculum and teaching approaches are to be gradually introduced at all education levels by 2023 (WEB, d). The reform introduces significant changes in the approach to general education, its competency-based education in the curriculum, and new teaching methods focusing on development of pupils' knowledge, skills and attitudes. It is also aimed at creating pupils' interest and positive attitude towards lifelong learning.

Teachers from all levels of the general education system were involved in creating the new curriculum and planning the organizational and managerial changes to be introduced in schools on a daily basis (WEB, d; WEB, e). In the framework of the ESF project, more than 1700 teachers from 100 pilot schools all over the country are involved in the approbation of the new curriculum and learning materials. By the end of 2021, approximately 6000 teachers will be given an opportunity to take part in teacher professional development sessions (WEB, c; WEB, d). In addition, by 2021 the National Centre for Education will have developed several e-learning training course modules. This specially designed self-paced e-learning course will be an important part of the education reform and lifelong learning for teachers. A repository of digital learning resources will be created, and all the e-learning course modules and other digital learning materials will be stored in a public domain. The courses will be developed taking into account the diverse technological skills and previous online learning experience (or lack of any) of the potential users (teachers-as-learners) (WEB, $\mathrm{d}$ ).

Online learning is an opportunity for teachers to participate in lifelong learning and develop individual learning skills with ability for self-determination and control over own learning. Learners' success in e-learning depends upon the self-discipline skills and daily routine study practices, which contribute to achieving personal goals and higher competence levels (Gorbunovs, Kapenieks, \& Cakula, 2016). E-learning readiness is determined by two factors: autonomous learning and technology usage self-efficacy. Piskurich (2003) mentioned two types of online learning readiness: technical readiness and psychological readiness. According to Coopasami, Knight and Pete (2017), learners' 
readiness for online learning should be evaluated before the course as it helps maximize e-learning.

In order to create a sustainable e-learning solution to lifelong learning, cultural acceptance of e-learning is crucial by both instructors and teachers-as-learners. A number of e-learning readiness surveys have been created for various institutions and researchers. Organizations develop and administer their own surveys before enrolment, and mostly they are targeted at a particular group of learners (Catalano, 2018). Researchers have selected a learning assessment survey tool named Test Of Online Learning Success (TOOLS) developed by Dr. Kerr at Texas Weslayan University (WEB, f). It is constructed of 45 questions emphasizing computer skills, self-regulation and independent learning, academic skills and the need for distance learning. TOOLS questionnaire is open source and is easy to replicate (Lee, 2016); its measure has a stable and simple structure, and it has been validated and proven to be test-retest reliable (Kerr, Rynearson, \& Kerr, 2006). However, there is a lack of studies investigating or assessing general educational personnel readiness for online learning in Latvia.

\section{Aims and Methodology}

The aim of the research was to measure the Latvian teachers' digital skills and their readiness to learn online and to search for the differences in results related to respondents' socio-demographic or professional characteristics. In the study, the term "teachers" is used to describe all specialists, who enter the class and teach any subject at school (from pre-primary school to upper secondary school), as well as all other professionals working at school, such as school director, educational methodologist, speech therapist, social educator, school psychologist, school librarian, teachers of interest education and others. In the study, the term "teachers-as-learners" refers to all of the above-mentioned professionals working in the sphere of general education who are the primary audience of the online learning course designed and implemented by the NCE.

\section{Development and Distribution of the Questionnaire}

The original TOOLS questionnaire (WEB, f) was translated into the local language and adapted for use in Latvia with some modifications from the original version. For example, "Computer skills" was replaced with "Digital skills" and relevant items modified with focus on the digital technologies, for example, "Dependent learning" was replaced with "Self-regulation skills", "Need for online learning" with "Need for distance studies". In some questions, the wording was changed because of the translation needs and the purpose of adaptation to the population under consideration. Furthermore, one question was completely omitted as not relevant for the population. We created a survey with 44 questions of Likert-type answers ranged from one (strongly disagree) to five (strongly agree). The online survey was performed from November 2017 to January 2018. All respondents were teachers (age 21-65), working at the pilot schools of the "Competency-Based Education" project carried out by the NCE (WEB, d).

The questionnaire was distributed by e-mail to all pilot schools of the project in question. We determined the sample size of the population according to literature, where sample size for $\pm 3 \%$ precision level (confidence level was $95 \%$ and $p=0.5$ ) was stated as follows: 
- if the size of population is 50000 , the sample size is 1087 ;

- if the size of population is 25 000, the sample size - 1064 (Israel, 1992).

We also performed a post-hoc analysis and according to it using "Academic skills" subscale the power of the study was 0.99 , i.e., the II type error was 0.01 .

We applied the principles of the Scientists' Code of Ethics (WEB, g) throughout the research - working according to the principles of scientists' ethics and legislation. The respondents were informed about the general purpose of the survey and research, about their right not to answer individual questions, about the voluntary nature of their participation in the research, as well as about anonymity and data confidentiality.

\section{Statistical Analysis}

Answers to individual questions were summarized in order to obtain the main variables of interest according to five previously defined subscales of the survey: "Digital skills" (11 questions), "Independent learning” (10 questions), "Self-regulation" (6 questions), "Need for distance studies" (5 questions), and "Academic skills" (13 questions). Additionally, the overall "Readiness to study online" was calculated as a sum of all questions; the mean value and standard deviation were used for further analysis. To evaluate the internal reliability, Cronbach's alpha was evaluated for all questions, as well as for each of the five subscales of the survey. Mean significance is mentioned in footnote of Table 4.

We calculated descriptive statistics for all study variables. Number and ratio of respondents were presented for the group variables. For continuous variables with normal distribution, means and standard deviations were presented. For non-normally distributed variables, median, $25^{\text {th }}$ and $75^{\text {th }}$ percentile, as well as minimal and maximal values were calculated.

The univariate analysis was performed to assess differences among participants according to the five subscales and "Readiness to study online". To assess differences between genders and dependent variables that had a normal distribution, an independent samples t-test was performed. For differences between genders in variables with nonnormal distribution, we performed a Mann-Whitney test. To assess differences between age groups and places of living, the one-way ANOVA test was conducted for the normally distributed variables, and Kruskal-Wallis test - for variables with distribution other than normal. Significance level less than $\alpha=0.05$ was considered statistically significant. The data were collected and processed with IBM Statistical Package for the Social Sciences (SPSS®) software Version 20 (WEB, h).

\section{Research Results}

The study sample consisted of 1092 participants, $95.1 \%$ of them were females, mostly lived in small cities $(42.5 \%)$. The largest age group presented was from 50 to 59 years $(38 \%)$ (Table 1$)$.

Only $0.4 \%$ of all the respondents taught children at all education levels (pre-primary school, lower secondary school and upper secondary school). These were mostly the teachers of arts (music, culture, and visual arts), sports and health or similar. $18.9 \%$ of the respondents were pre-primary school teachers. 
Internal consistency of the entire measure was good (Cronbach's alpha 0.82), as well as for individual subscales of the survey (Table 2). The obtained results were similar to those of the original TOOLS measure (Kerr et al., 2006).

Table 1

Socio-Demographic Characteristics of Study Population

\begin{tabular}{|c|c|c|c|}
\hline Teachers-as-learners' socio-demographic characteristics & Group & $\mathrm{N}$ & $\%$ \\
\hline \multirow{2}{*}{ Gender } & Female & 1038 & 95.05 \\
\hline & Male & 54 & 4.95 \\
\hline \multirow{5}{*}{ Age group } & $18-29$ & 55 & 5.04 \\
\hline & $30-39$ & 150 & 13.74 \\
\hline & $40-49$ & 393 & 35.99 \\
\hline & $50-59$ & 415 & 38 \\
\hline & $60-69$ & 79 & 7.23 \\
\hline \multirow{4}{*}{ Place of living* } & Riga** & 123 & 11.26 \\
\hline & Big cities & 187 & 17.12 \\
\hline & Small cities & 464 & 42.49 \\
\hline & Rural areas & 318 & 29.12 \\
\hline
\end{tabular}

* Classification taken from the Central Statistics Bureau in Latvia

$* *$ Riga - the Capital of Latvia

Table 2

Internal Consistency (Cronbach's alpha) of Study Subscales

\begin{tabular}{lcc}
\hline \multicolumn{1}{c}{ Subscale } & Our questionnaire & TOOLS questionnaire \\
\hline Digital skills & 0.90 & 0.84 \\
\hline Independent learning & 0.79 & 0.83 \\
\hline Self-regulation skills & 0.66 & 0.70 \\
\hline Need for distance studies & 0.76 & 0.63 \\
\hline Academic skills & 0.74 & 0.68 \\
\hline Entire measure (all scales) & 0.82 & 0.84 \\
\hline
\end{tabular}

"Readiness to study online" and five subscales ("Independent learning", "Selfregulation", "Need for distance studies" and "Academic skills") had normal distribution. The only variable that had other distribution than the normal one was "Digital skills". From all the subscales, the relatively lowest standard deviation was observed for "Academic skills" (4.62 or $10.16 \%$ out of 45.47), followed by "Independent learning" (4.28 or $10.57 \%$ out of 40.51 ), while "Self-regulation" had the largest standard deviation (3.04 or $17.07 \%$ ). The largest range of answers was for "Need for distance education" ( $\min 24, \max 63)$ and “Digital skills" (min 20, $\max 55)$ (Table 3$).$ 
Table 3

Descriptive Statistics of the Summarized Variables - Five Subscales of the Survey and Readiness to Study Online

\begin{tabular}{lccccc}
\hline \multicolumn{1}{c}{ Variable } & Mean & Median & Std. Dev. & Min & Max \\
\hline Digital skills & 46.72 & 48 & 6.29 & 20 & 55 \\
\hline Independent learning & 40.51 & 40 & 4.28 & 24 & 50 \\
\hline Self-regulation & 17.81 & 18 & 3.04 & 7 & 25 \\
\hline Need for distance education & 25.41 & 25 & 3.69 & 12 & 39 \\
\hline Academic skills & 45.47 & 45 & 4.62 & 24 & 63 \\
\hline Readiness to study online & 162.26 & 163 & 12.04 & 99 & 198 \\
\hline
\end{tabular}

Statistically significant differences were found for all six variables by education levels and the socio-demographic characteristics of respondents, namely, by age group, place of living and gender.

We found that males had higher rates for "Digital skills" than females. Younger respondents (age group 18-29 and 30-39) had higher digital skills than older respondents. Teachers living in Riga and other big cities reported the highest results, while teachers living in rural areas had the lowest rates in the "Digital skills" subscale (Table 4).

For "Independent learning" it was found that respondents' teaching grades $1-3$ in group 18-29 showed higher results than group 40-49. Additional differences by age group (ANOVA $F=2.51, p=0.04$ ) and by place of living (ANOVA $F=3.17, p=0.03$ ) were found in grades 4-6 (Table 4).

Males had higher rates in "Self-regulation" than females, and respondents from big cities had higher rates than individuals living in rural areas (Table 4). Differences by age were observed at the pre-primary level (ANOVA $F=2.66, p=0.03$ ).

Difference in "Need for distance studies" was observed in grades 10-12, where males had a higher need for online studies than females (Table 4). Respondents from age group 18-29 had higher results in "Academic skills" than groups 40-49 and 50-59. Respondents living in the rural areas had lower results in "Academic skills" than those who lived in small cities (Table 4). Pre-primary school teachers' rates were different by age group as well (ANOVA $F=2.74, p=0.03$ ).

In general, males showed higher rates of "Readiness to learn online" than females and younger respondents (age groups 18-29, 30-39) had higher rates than older respondents (Table 4). Statistically significant differences in "Readiness to learn online" by respondents' place of living were observed only in the group working with grades 4-6. It was found that teachers in big republican cities had higher readiness to study online than teachers living in rural areas (Table 4).

Table 4

Differences in Results by Education Level, Gender, Age and Place of Living

\begin{tabular}{cccc}
\hline & \multicolumn{4}{c}{ Differences in "Digital skills” } & \\
\hline Education level & Gender & Age & Place of living \\
\hline pre-school & $p=0.41$ & $p<0.01$ & $p=0.87$ \\
\hline grades 1-3 & $p=0.53$ & $p<0.01$ & $p=0.10$ \\
\hline grades 4-6 & $p=0.03^{*}$ & $p<0.01$ & $p<0.01$ \\
\hline
\end{tabular}


Continuation of Table 4

\begin{tabular}{|c|c|c|c|}
\hline grades $7-9$ & $p<0.01$ & $p<0.01$ & $p=0.03 *$ \\
\hline grades $10-12$ & $p<0.01$ & $p<0.01$ & $p=0.25$ \\
\hline \multicolumn{4}{|c|}{ Differences in "Independent learning" } \\
\hline Education level & Gender & Age & Place of living \\
\hline pre-school & $p=0.99$ & $p=0.08$ & $p=0.98$ \\
\hline grades $1-3$ & $p=0.38$ & $p=0.02 *$ & $p=0.48$ \\
\hline grades $4-6$ & $p=0.43$ & $p=0.04 \%$ & $p=0.02 *$ \\
\hline grades $7-9$ & $p=0.66$ & $p=0.15$ & $p=0.32$ \\
\hline grades $10-12$ & $p=0.35$ & $p=0.41$ & $p=0.70$ \\
\hline \multicolumn{4}{|c|}{ Differences in "Self-regulation skills" } \\
\hline Education level & Gender & Age & Place of living \\
\hline pre-school & $p=0.35$ & $p=0.03 *$ & $p=0.02 *$ \\
\hline grades $1-3$ & $p=0.41$ & $p=0.41$ & $p=0.18$ \\
\hline grades $4-6$ & $p=0.14$ & $p=0.47$ & $p=0.84$ \\
\hline grades $7-9$ & $p=0.67$ & $p=0.18$ & $p=0.68$ \\
\hline grades $10-12$ & $p<0.01$ & $p=0.44$ & $p=0.54$ \\
\hline \multicolumn{4}{|c|}{ Differences in "Need for distance learning" } \\
\hline Education level & Gender & Age & Place of living \\
\hline pre-school & $p=0.98$ & $p=0.96$ & $p=0.11$ \\
\hline grades $1-3$ & $p=0.99$ & $p=0.44$ & $p=0.10$ \\
\hline grades $4-6$ & $p=0.22$ & $p=0.57$ & $p=0.20$ \\
\hline grades $7-9$ & $p=0.13$ & $p=0.79$ & $p=0.14$ \\
\hline grades $10-12$ & $p=0.02 *$ & $p=0.71$ & $p=0.77$ \\
\hline \multicolumn{4}{|c|}{ Differences in "Academic skills" } \\
\hline Education level & Gender & Age & Place of living \\
\hline pre-school & $p=0.31$ & $p=0.03 *$ & $p=0.45$ \\
\hline grades $1-3$ & $p=0.79$ & $p<0.01$ & $p<0.01$ \\
\hline grades $4-6$ & $p=0.87$ & $p=0.02 \%$ & $p=0.16$ \\
\hline grades $7-9$ & $p=0.65$ & $p=0.13$ & $p=0.23$ \\
\hline grades $10-12$ & $p=0.51$ & $p=0.17$ & $p=0.79$ \\
\hline \multicolumn{4}{|c|}{ Differences in "Readiness to study online" } \\
\hline Education level & Gender & Age & Place of living \\
\hline pre-school & $p=0.66$ & $p<0.01$ & $p=0.62$ \\
\hline grades $1-3$ & $p=0.73$ & $p<0.01$ & $p=0.09$ \\
\hline grades $4-6$ & $p=0.04 *$ & $p<0.01$ & $p<0.01$ \\
\hline grades $7-9$ & $p=0.02 \%$ & $p<0.01$ & $p=0.36$ \\
\hline grades $10-12$ & $p=0.03 *$ & $p<0.01$ & $p=0.83$ \\
\hline
\end{tabular}

* The mean difference is significant at the 0.05 level.

\section{Discussion}

The main aims of the research were to measure Latvian teachers' digital skills and their readiness to study online as well as to find differences in readiness to study online related to respondents' socio-demographic and professional parameters. Statistically significant differences in results by respondents' gender, place of living and age group were found in accordance with the aim of the research. 
In relation to the gender differences, we found that males had a higher level of "Digital skills" and "Readiness to study online" than females at all education levels. These findings are consistent with the findings of Broos (2005) on the so-called "digital gender divide" - in her study females had more negative attitude towards the Internet and computers than males; males had less computer anxiety than females. Broos also found that more experience with computers resulted in less anxiety for males. In our research, males showed higher rates in "Need for distance study" (Broos, 2005). This leads to assumption that males would be more open for online learning because of their work schedules, geographical location or they would prefer studying at their own pace and according to their own choice, and their experience working with computer would allow them to perform their learning distantly.

We also observed that younger teachers (age group 18-29) in grades 1-3 showed better results in "Independent learning skills", and this let us assume that for younger teachers it would be easier to participate in the self-paced learning. In addition, our research revealed that male teachers of grades 10-12 had a higher rate in "Self-regulation skills" than females. Females would more likely need support from "outside" - either from the e-learning system itself with reminders about the e-learning course or from peers to plan time and successfully participate in the course. This finding is consistent with the findings of Mayes and de Freitas (2013) on self-regulated learning. It is especially needed in self-paced online learning courses, where either the system or the learner has to monitor and control the learning process (Mayes \& de Freitas, 2013). According to Merriënboer and Kester (2014), learners should master choosing their learning trajectories and monitor their performance after completion of the learning task (self-assessment), and be able to select new learning tasks (Mayer, 2014). Teachers-as-learners need support to develop their self-regulating skills. Developing self-evaluation ability for adult learners means that their self-regulating techniques are developed and adults become more confident learners (Suwanarak, 2018). Self-directed learning and control are important components in readiness for online learning. To design effective high-quality e-learning courses, potential learners' characteristics should be evaluated from the initial phases of course planning; self-directed learning readiness is closely related to learners' achievements (Park, Lee, \& Bae, 2010). According to our study, females will need more help in the development of self-regulating abilities.

Our findings revealed that younger teachers (18-29, 30-39) had a significantly higher level of perceived "Digital skills" than older respondents. This corresponds with Beetham (2013), who claims that it is necessary to consider learners' competence and previous experience with learning in the respective form (online). It is a challenge for educators in a learner-centred approach, where digital capability cannot be seen as separate from learner's age, gender or culture. Necessity for social support and being able to "play around" with technology is considered the most important need of older adults (Tsai, Shillair, \& Cotten, 2017) to learn new technology. Although in the research we did not focus on adults aged above 65 , we still consider social support to be a crucial issue for learners with computer anxiety and negative attitude towards new technologies and the Internet.

Similar patterns were observed in the results of "Digital skills" and "Readiness to study online" subscales: younger teachers had higher rates. This allows us to assume that teachers-as-learners' general readiness for lifelong learning in form of online learning is very closely related to their digital skills. In order to implement a successful online 
course for teachers-as-learners, the content should be adapted to those lifelong learners who are older than 39 , in order to help improve their digital skills before they start learning or during the course by personalizing the learning path and introducing various topics on ICT skill improvement.

Similar to our research, Wladis and Samuels developed a survey of twelve questions and discovered that collecting data on learners' characteristics helped predict their success in learning online much better than online readiness survey results (Wladis \& Samuels, 2016). Formative checks or other self-reporting form for the learners should be used in order to get to know them better, including their gender, age and cultural background (Beetham, 2013). We recommend responsible authorities to assess the online learning readiness and to collect data on learners' socio-economical and professional characteristics when they enrol in the e-learning course. Such an activity would save time and resources both for the learners and for instructors and introduce the self-paced learning principles. According to the results of such an assessment, a more personalized learning path can be calculated within the limits of the available technology. Our recommendation goes in line with Hobbs and Coiro's (2019) suggestion to personalize the learning, where customization should be done using big data captured from learners' activity in the course. Learning path should be built by programming algorithms suggesting next tasks for the learner (Hobbs \& Coiro, 2019).

Computer skills and participants' motivation should be tested in order to evaluate whether they meet the requirements of the course. It is emphasized that learners must have basic ICT skills to be able to focus on studies and not on a lack of skills to successfully participate in the learning process (Okinda, 2014).

As the NCE is interested in a larger number of successful e-learners who complete the self-paced e-learning course, we recommend introducing special tasks and topics that will improve digital skills of learners and increase their readiness for online learning and ability to successfully complete the course. When learners take full responsibility of what they learn, deeper learning may happen (Beetham, 2013).

There are some limitations of the study:

- respondents represented only the pilot schools $(n=100)$ of the project "Competency-Based Education" carried out by the NCE selected from all regions of Latvia based on choice of the local regional authorities (WEB, d);

- it was a self-assessment survey - the answers were evaluated by participants themselves; therefore, it can be rather subjective;

- differences were analysed based on 0.05 significance level; however, it could change by increasing the number of participants in the case of borderline significance;

- according to the OECD, in 2018 there were $89 \%$ of female teachers in Latvia (Schwabe, 2019), according to the Central Statistical Bureau of Latvia, in 2018 there were $90.2 \%$ of female teachers (general education and pre-school) (WEB, a). We acknowledge the sample size of our study is close to the population; however, male/female percentage of teachers in the Latvian population is a dynamic parameter, where the proportion of females is growing each year.

We see the following discussion points as the strengths of our research:

- Large sample study is the major strength of the present study ( $\mathrm{n}=1092$ ). According to the post-hoc calculation using "Academic skills" subscale, the power of the study is 0.99 , i.e., the type II error is 0.01 . 
- Another strength of the study is being the first scientific research on e-learning readiness within the region and with teachers-as-students as respondents. It is important that such a survey is carried out before launching massive e-learning course for all teachers in general education on the new curriculum and teaching approaches. As the education reform is a governmental project, part of the research results will be applied to develop the e-learning environment for teachers' course.

\section{Conclusion}

The research contributes to the theoretical framework of teachers-as-learners' readiness for online learning, especially when analyzing teachers-as-learners in online environment.

Learning path in the e-course should be customized, taking into account learners' socio-demographic parameters and online learning readiness rate. In a self-paced e-learning course, the system should select the on-boarding materials for each learner, based on the data obtained from learners' self-evaluation during enrolment in the course. Later, during the course, short self-evaluation forms should be built-in to follow the learners' path and progress.

One of the problems of the Latvian education system is the low prestige of the teachers' profession, which has caused a decrease in the number of students in teachers' study programs and ageing teaching workforce. E-learning course designers for teachersas-learners should be mindful of the various levels of digital skills and online learning readiness of the teachers in different age groups. Additional on-boarding activities or special learning materials should be developed for learners older than 39 to reduce the computer anxiety and develop their ICT skills for successful e-learning experience. For the sustainability of the Latvian education reform to be implemented from 2019, it is important to encourage and develop both technical and psychological readiness of the teachers-as-learners.

\section{Implications for Future Research}

The authors will continue research on relationships between the online learning readiness and other characteristics of the teachers-as-learners (subject taught, number of subjects taught, latest education obtained and suchlike).

Theoretical sources and research on the online learning course design and successful online learning experience will be analyzed to develop suggestions for a customized learning path in online courses for teachers-as-learners.

\section{Acknowledgments}

Technology Enhanced Learning E-ecosystem with Stochastic Interdependences TELECI. No.1.1.1.1/16/A/154.

Special thanks from Mrs. Evija Mirke to Teacher Mrs. İrisa Celma for her support and inspiration. 


\section{References}

Beetham, H. (2013). Designing for active learning in technology-rich contexts. In Beetham, H. \& Sharpe, R. (Eds.), Rethinking pedagogy for a digital age ( $2^{\text {nd }}$ edition) (pp. 94-157). New York, USA: Taylor \& Francis.

Broos, A. (2005). Gender and information and communication technologies (ICT) anxiety: Male self-assurance and female hesitation. CyberPsychology \& Behavior, 8(1), 21-31. doi: https://doi.org/10.1089/cpb.2005.8.21

Catalano, A. J. (2018). Measurements in distance education: A compendium of instruments, scales, and measures for evaluating online learning. New York: Routledge.

Coopasami, M., Knight, S., \& Pete, M. (2017). e-Learning readiness amongst nursing students at the Durban University of Technology. Health SA Gesondheid, 22, 300306. doi: https://doi.org/10.1016/j.hsag.2017.04.003

Franzenburg, G. (2017). Learning from the past for the future: How to make adult education sustainable. Discourse and Communication for Sustainable Education, 8(2), 57-65. doi: https://doi.org/10.1515/dcse-2017-0015

Gorbunovs, A., Kapenieks, A., \& Cakula, S. (2016). Self-discipline as a key indicator to improve learning outcomes in e-learning environment. Procedia - social and behavioral sciences, 231 (International Conference. Meaning in Translation: Illusion of Precision, MTIP2016, 11-13 May 2016, Riga, Latvia), 256-262. doi: https://doi. org/10.1016/j.sbspro.2016.09.100

Hobbs, R., \& Coiro, J. (2019). Design features of a professional development program in digital literacy. Journal of Adolescent and Adult Literacy, 62(4), 401-409. doi: https://doi.org/10.1002/jaal.907

Israel, G. D. (1992). Determining sample size 1 the level of precision. University of Florida Cooperative Extension Service. Retrieved from https://www.academia.edu/ 21353552/Determining_Sample_Size_1

Kapenieks, J., \& Salite, I. (2013). Action research for creating knowledge in an e-learning environment. Journal of Teacher Education for Sustainability, 14(2), 111-129.

Kerr, M. S., Rynearson, K., \& Kerr, M. C. (2006). Student characteristics for online learning success. The Internet and Higher Education, 9(2), 91-105. doi: https://doi.org/10.1016/j.iheduc.2006.03.002

Lee, D. E. (2016). Study of the predictive value of the test of online learning success. San Francisko State University. Retrieved from https://sfsu-dspace.calstate.edu/ bitstream/ handle/10211.3/173177/AS352016EDDL44.pdf? sequence=1

Mayer, R. E. (Ed.). (2014). The Cambridge handbook of multimedia learning (2 $2^{\text {nd }}$ edition). New York: Cambridge University Press.

Mayes, T., \& de Freitas, S. (2013). Technology-enhanced learning. In Beetham, H. \& Sharpe, R. (Eds.), Rethinking pedagogy for a digital age ( $2^{\text {nd }}$ edition) (p. 324). New York, USA: Taylor \& Francis. doi: https://doi.org/10.4324/9780203961681

Okinda, R. A. (2014). Assessing e-learning readiness at the Kenya Technical Teachers College Commonwealth of Learning CC BY SA. Retrieved from http://dspace.col. org/bitstream/handle/11599/1699/2014_JL4Dv1n3_Okinda_AssessingeLearning. pdf? sequence $=1 \&$ xisAllowed $=y$

Park, J.-H., Lee, E., \& Bae, S. H. (2010). Factors influencing learning achievement of nursing students in e-learning. Journal of Korean Academy of Nursing, 40(2), 182190. doi: https://doi.org/10.4040/jkan.2010.40.2.182 
Piskurich, G. M. (2003). Preparing learners for e-learning. (R. Taff, Ed.). San Francisco, CA: Pfeiffer.

Salìte, I. (2009). Educational action research for sustainability: Constructing a vision for the future in teacher education. Journal of Teacher Education for Sustainability, 10(1), 5-16. doi: https://doi.org/10.2478/v10099-009-0021-6

Salìte, I., Drelinga, E., Iliško, Dz., Oḷehnoviča, E., \& Zariņa, S. (2018). Sustainability from the transdisciplinary perspective: An action research strategy for continuing education program development. Journal of Teacher Education for Sustainability, 18(2), 135-152. doi: https://doi.org/10.1515/jtes-2016-0020

Schwabe, M. (2019). Latvia - Country Note - TALIS 2018 Results. Volume I: Teachers and school leaders as lifelong learners. Retrieved from https://www.oecd.org/ education/talis/TALIS2018_CN_LVA.pdf

Suwanarak, K. (2018). Self-evaluation of Thai adult learners in English writing practice. 3L: Language, Linguistics, Literature, 24(2), 95-111. doi: https://doi.org/10.17576/ 3L-2018-2402-08

Tsai, H.-Y. S., Shillair, R., \& Cotten, S. R. (2017). Social support and "playing around": An examination of how older adults acquire digital literacy with tablet computers. Journal of Applied Gerontology, 36(1), 29-55. doi: https://doi.org/10.1177/0733464 815609440

Wladis, C., \& Samuels, J. (2016). Do online readiness surveys do what they claim? Validity, reliability, and subsequent student enrollment decisions. Computers \& Education, 98, 39-56. doi: https://doi.org/10.1016/J.COMPEDU.2016.03.001

WEB (a). Central Statistical Bureau of Latvia. Education institutions and enrolment (at the beginning of the school year). Retrieved from https://www.csb.gov.lv/en/ statistics/statistics-by-theme/social-conditions/education/tables/izg010/educationinstitutions-and-enrolment-beginning

WEB (b). PISA 2015 key findings for Latvia. Retrieved from http://www.oecd.org/ latvia/pisa-2015-latvia.htm

WEB (c). National Centre for Education in Latvia. (2016). On the way to competencybased curriculum. Retrieved from https://www.izm.gov.lv/images/izglitiba_visp/ Konferences_Tagad/VISC_-_Ceḷā_uz_kompetenču_pieeju_mācībām.pdf (in Latvian).

WEB (d). National Centre for Education in Latvia. (2016). Project application for European social fund competency-based curriculum. Retrieved from https://visc.gov. lv/visc/projekti/dokumenti/esf_831/20161101_apraksts.pdf (in Latvian).

WEB (e). Ministry of Foreign Affairs in Latvia. (2018). Latest reforms. Retrieved from https://www.mfa. gov.lv/en/policy/society-integration/minority-education-in-latvia/ latest-reforms

WEB (f). Test of online learning success (TOOLS). Retrieved from http://www.txwescetl. com/about-distance- ed/for-students/

WEB (g). Latvian Academy of Sciences. Code of ethics for scientists - Latvijas Zinātņu Akadēmijas Vēstis. Retrieved from http://www.lasproceedings.lv/en/code-of-ethicsfor-scientists/

WEB (h). IBM SPSS software. Retrieved from https:/www.ibm.com/analytics/spssstatistics-software? $\mathrm{mhq}=\% 27 \mathrm{spss}$

Correspondence concerning this paper should be addressed to Sarma Cakula, Professor, “Smiltini””, Marupe district, LV-2166, Riga region, Latvia. Email: sarma.cakula@va.lv 